\title{
The Role of The WTO in Mediate Dispute Palm Oil between Indonesia and the European Union
}

\author{
Yana Sylvana $^{1}$, Yohanes Firmansyah ${ }^{2}$, Hanna Wijaya ${ }^{3}$, Michelle Angelika S \\ ${ }^{1234}$ Health Law Postgraduate Student, Pembangunan Negeri Veteran Jakarta \\ University \\ *Coresponding author: ${ }^{1}$ sylvanayana@gmail.com, ${ }^{2}$ yohanesfirmansyab28@gmail.com, \\ 3hannwijaya@yahoo.com, ${ }^{4}$ michelleangelika111@gmail.com
}

\begin{abstract}
Several major European countries, such as France and Germany, have included CPO in the list of non-environmentally friendly products. Some countries impose additional import duties because $\mathrm{CPO}$ is considered as damaging as alcohol. This research is descriptive and uses a normative juridical approach. There are several demands put forward by the European Union for palm oil entering its territory, these demands include the importation of palm oil, either for food or for industrial purposes. Hence, the European Union requires sustainable palm oil production. Besides, the European Union believes that the use of palm oil for fuel production will endanger the sustainability of other foodstuffs, especially for the poor. The European Union's accusation of environmental threats is considered impure as environmental protection. Many argue that the accusation is only a political step by the European Union in anticipating the development of exports of Indonesian CPO products to Europe.
\end{abstract}

Keywords: World Trade Organization, Palm Oil, Indonesia, and the European Union

\section{Introduction}

Indonesia is a tropical country that is rich in biodiversity, one of the plant varieties that thrives on Indonesian soil is Palm Oil, or in the scientific language, it is called Elaeis, which is an industrial plant producing industrial oil, cooking oil, and fuel (biodiesel). Palm oil produced by palm oil in the form of Crude Palm 
Oil (CPO) is one of Indonesia's leading commodities, and palm oil is a plant that is experiencing rapid growth compared to other plantation crops. Therefore, Indonesia is known as the second-largest producer and exporter of palm oil in the world after India, the export volume of Indonesian palm oil in January July 2017 reached 18.15 million tons, while in the same period in 2018, the volume of palm oil exports increased to 18,52 million tonnes. 1 Total production and export value are interrelated and mutually supportive. As is the case, the increase in the export of this commodity is inseparable from the higher level of productivity as expressed by Casson in Tuti Ermawati that increased palm oil production This could be due to several factors, including the efficiency and availability of harvested land, low production costs, promising domestic and international markets, and government policies that encourage the development of the palm oil industry. ${ }^{1}$

Palm oil to Indonesia can be viewed as a yellow diamond. Especially since 1970, palm oil has become one of the most important commodities in Indonesia. In the scarcity of energy sources, palm oil is present as an alternative. Besides, palm oil is also important in various types of food and non-food industries. The percentage of palm oil used for the food industry reaches $80 \%$, for the cosmetic industry, it reaches $19 \%$, and the remaining $1 \%$ is used for the biodiesel industry to meet renewable energy needs. The total world production of palm oil is estimated at more than 45 million tonnes, with Indonesia and Malaysia as the world's main producers and exporters. Indonesia dominates the world market as much as $47.6 \%$ of the total world palm production. Indonesia's oil palm area reaches 8.4 million hectares. According to Gapki's records, 52\% were cultivated by private companies, $42 \%$ were smallholder oil palm plantations, and $6 \%$ were cultivated by state-owned companies. The existence of this oil palm plantation is also the answer to the lack of jobs in Indonesia. The plantation sector contributes around 108 thousand jobs each year, especially oil palm plantations. ${ }^{2}$

The European Union is the 2nd largest export destination for Indonesia and the 3rd source of imports for Indonesia in 2012. In the last five years, trade between the two parties has increased by $8.5 \%$ per year. During 2013, total trade between Indonesia and the European Union reached USD 31.8 billion or decreased by $0.9 \%$ from USD 32.1 billion in 2012. Indonesia's exports to the European Union in 2013 reached USD 18.1 billion or an increase of $0.6 \%$

\footnotetext{
1 (Ernawati and Yeni 2013)

2 World Growth Report, "The Economic Benefit of Palm Oil to Indonesia," 2011.
} 
compared to 2012, with a figure of USD 18 billion. The main export commodity is dominated by agricultural products, especially palm oil and its derivatives. The European Union with 28 member countries (EU-28) is the 2nd largest export market for Indonesian palm oil. In 2013, Indonesia's palm oil exports to the European Union reached 3,730,000 per metric ton (MT), with a value of USD 2.85 billion. (Mulyati, 2013). Europe's need for palm oil is quite large. Europe needs 6 million tonnes of palm oil annually. Meanwhile, Indonesia is only able to export 2.5 million tons. The largest exporter of palm oil in Europe to date in Latin America. ${ }^{3}$

The crude palm oil (CPO) industry with HS code 151110, is an important contributor to the economy in Indonesia. This industry contributes to regional development as well as an important resource for poverty alleviation through agricultural cultivation and subsequent processing. $\mathrm{CPO}$ production is also the type of income that many rural poor in Indonesia can rely on. This is evidenced by the jobs provided by the palm oil production sector. More than 6.6 million tonnes of palm oil is produced by smallholders who own more than 41 percent of total oil palm plantations. ${ }^{45}$

Since 2004 the use of CPO commodity has occupied the highest position in the world vegetable oil market, reaching around 30 million tons with an average growth of $8 \%$ per year, beating the soybean oil commodity of around 25 million tons with an average growth of 3.8\% per year. One of the largest CPO consumers and a potential market for Indonesia is the European Union. This area uses $\mathrm{CPO}$ as the main raw material in the transportation sector to be able to produce biofuels, which are biofuels in the form of various types of plants, which is a renewable energy that is being developed by the European Union as a form of its concern in overcoming environmental problems. This technology was created to overcome energy scarcity by utilizing renewable resources. To be able to produce biofuel, European Union countries import CPO from Indonesia. So it is not surprising that Indonesia's CPO export production to the European Union continues to increase from year to year. If you look at the export duty (BK) on CPO and its derivatives from 2007-2012, the palm oil industry has

3 N U Sally, "Sengketa Minyak Sawit Antara Indonesia Dan Uni Eropa," Dauliyah Journals 1, no. 1 (2016): 1-11, https://doi.org/10.1186/s40563-016-0062-8.

4 Bradley, Alexander. 2019. "Pengaturan Hukum Terhadap Produk CPO (Crude Palm Oil) Dan Dampak Terhadap Perdagangan Internasional." Universitas Sumatra Utara. Medan: Skripsi

5 Alexander Bradley, "Pengaturan Hukum Terhadap Produk CPO (Crude Palm Oil) Dan Dampak Terhadap Perdagangan Internasional” (USU, 2019). 
contributed Rp. 79.4 trillion. This means that the palm oil industry has proven to be a savior of the country's foreign exchange. ${ }^{6}$

However, recently the European Union began to make various regulations on environmental standards in various industries. In 2003, the European Union passed the Forest Law Enforcement Governance and Trade (FLEGT), which regulates imports in the forestry sector, made regulations related to pulp and paper imports in 2008, and penalized anti-dumping tariffs on exports of biodiesel and fatty alcohol from Indonesia to European Union. And the latest is the policy that regulates biofuel originating from palm oil, namely the Renewable Energy Directive (RED). ${ }^{7}$

RED is a policy aimed at controlling the Uni Eropa in reducing greenhouse gas emissions at least $20 \%$ and increasing the use of renewable energy by $20 \%$ in energy consumption by 2020. Uni Eropa is also committed to increasing the emission reductions of up to $30 \%$ in 2020 when a global climate change agreement has been reached. RED also highlights the issue of renewable energy in the transportation sector with the use of biofuels, where RED sets a binding target of $10 \%$ for 2020 . Through RED, Indonesian palm oil exports to Europe are subject to anti-dumping rates of up to 178.85 euros per tonne. These tariffs resulted in a drastic reduction in Indonesia's biodiesel exports to the EU, from 1.2 million tonnes in 2012 to 387 thousand tonnes in 2013, a decrease of 66 percent. 8 Even in August 2015, for the first time, global CPO prices fell to their lowest level for the last six years. The CPO price fell below the US $\$ 600$ per metric ton. However, low global CPO prices did not necessarily boost Indonesia's palm oil export volume. Indonesian palm oil exports at a time when the $\mathrm{CPO}$ price was at its lowest price due to the weak purchasing power of Indonesia's main export market, namely the European Union. ${ }^{8}$

\section{Research Methods}

This journal uses yuridical reviewing research methodology normative. Normative legal research is carried out by analyzing the synthesis of deductive conclusions from the statements contained in data sources such as library materials including journals, books, documents, literature or secondary legal

6 Report, "The Economic Benefit of Palm Oil to Indonesia."

7 Oloff Skoog, "Facts about the EU and Palm Oil," The Jakarta Post, 2015.

8 Rosita Dewi, "Implementasi Renewable Energy Directive Uni Eropa, Dalam Jurnal Interdependence," Jurnal Interdependence 1 (2013): 151. 
practice such as laws, legal theory, court decisions, expert opinions relevant and related to the issues discussed in this journal. The approaches used include statutory, conceptual, and analytical approaches. This research is a prescriptiveanalytical which data synthesis, discussion, and conclusions are analyzed in the form of qualitative research. ${ }^{9}$

\section{Results and Discussion}

\subsection{The role of the WTO in Dispute Resolution between Indonesia and the European Union}

The World Trade Organization is an organization that regulates international trade, which is founded on a series of agreements negotiated and agreed upon by a large number of countries in the world and ratified by parliament. The purpose of the agreement of these WTO agreements is to assist producers of goods and services, exporters, and importers in carrying out their activities, namely international trade. Organizations that formed since the 1995's to protect and embrace the interests of developing countries by providing treatment and different preferences as stated in the agreement General Agreement On tariffs and Trade (GATT) 1947 and the GATT 1994, which states that basically state - developed countries acknowledge that developing countries need to have the opportunity to increase their role in world trade. Therefore developed countries do not demand reciprocity in their negotiations with developing countries and give high priority to the elimination of trade barriers that concern the interests of developing countries. One of the international trade disputes that have been intensifying lately is the feud between the European Union and Indonesia. Starting from January 17, 2018, when a poll was held by the European Parliament to make decisions on the use of palm oil for biodiesel products. The decision was made to increase energy efficiency by up to 35 percent by $2030 .{ }^{10}$

The European Parliament approved a plan to ban the use of palm oil as the main raw material for biodiesel by 2021. Previously, on April 23, 2009, the European Union formed an overall policy for the production and promotion of energy from renewable sources in the European Union, namely the Renewable Energy Directive (RED). The introduction of RED by the European Union is a

9 Johny Ibrahim, Teori \& Metodologi Penelitian Hukum Normatif, 2006.

10 Sekar Wiji Rahayu and Fajar Sugianto, "IMPLIKASI KEBIJAKAN DAN DISKRIMINASI PELARANGAN EKSPOR DAN IMPOR MINYAK KELAPA SAWIT DAN BIJIH NIKEL TERHADAP PEREKONOMIAN INDONESIA," Jurnal Ilmu Hukum 16 (2020). 
first step for the European Union to reduce carbon emissions globally as a form of the European Union's commitment to the Kyoto Protocol.12 With the RED, countries in the European Union must ensure that there is at least 10 percent of friendly transportation fuels the environment they create is made from renewable sources. This is also done by the European Union to ensure that such transportation is produced in a sustainable and environmentally friendly manner. Apart from being intended to preserve the environment and reduce global emissions, the European Union's action in establishing RED is considered a new form of the barrier created by the European Union to protect biofuel products from the country because so far, the European Union is the main producer of biodiesel. The European Union is considered to have always been at the forefront of creating environmentally-friendly renewable energy. However, it does not deny that the European Union is the second-largest oil and gas consumption in the world after the United States. In the Delegated Regulation Supplementing Directive of the EU Renewable Energy Directive II (RED II), it is stated that there is a plan to end the use of palm oil as a biofuel in the European Union in 2030 and the reduction in the use of palm oil will start in 2024. The reason for its enforcement The prohibition against the use of palm oil is because palm oil is considered a major factor in environmental destruction. Based on this, Indonesia objected to the European Union's decision to stop palm oil export-import activities to the European Union because these policies limit market access for palm oil and palm oil-based biofuels so that they harm exports of Indonesian palm oil products in the market. European Union. ${ }^{11}$

\subsection{Forms of International Trade Dispute Resolution}

The dispute settlement forum in international trade law is, in principle, the same as the forum known in (international) dispute resolution law in general. The forum is negotiation, inquiry, mediation, conciliation, arbitration, legal or court settlement, or other dispute resolution methods chosen and agreed upon by the parties.

1. Negotiation Consultation is the most basic and oldest method of dispute resolution. Settlement through negotiation is the most important way. Many disputes are resolved every day by these negotiations without

11 Anggi Mariatulkubtia, "Peran WTO Dalam Menjembatani Benturan Kepentingan Antara Uni Eropa Dan Indonesia Dalam Perdagangan Biodiesel," Andalas Journal of International Studies (AJIS) 9, no. 1 (2020): 16, https://doi.org/10.25077/ajis.9.1.16-33.2020. 
any publicity or drawing public attention. The main reason is that this way, the parties can oversee the dispute resolution procedure. Each settlement is also based on the agreement or consensus of the parties.

2. Mediation is a method of settlement through a third party. He can be an individual (entrepreneur) or an institution or professional or trade organization. Mediators participate actively in the negotiation process. Usually, he, in his capacity as a neutral party, is to reconcile the parties by providing dispute resolution suggestions.

3. Conciliation has something in common with mediation. Both of these means involve a third party to settle the dispute peacefully. Conciliation and mediation are difficult to distinguish.

4. Arbitration is the voluntary submission of a dispute to a neutral third party. These third parties can be individual, institutionalized arbitration, or ad hoc arbitration. Arbitration boards are becoming increasingly popular these days. Nowadays, arbitration is increasingly being used in resolving national and international trade disputes.

5. Courts (National and International) Possible methods of resolving disputes other than the above are through national or international courts. The use of this method is usually taken if the existing solutions are not successful.

6. Applicable Law Legal issues that will be enforced or applied by the judiciary, including arbitration, are one of the crucial issues in international contract law, including in international trade law. The problem is that the applicable law determines legal certainty, especially for judicial bodies that they have implemented the law correctly. In this case, the judiciary does not take shortcuts in applying the law to a dispute that is brought before it.

This freedom of the parties seems to have become a general law principle. This means that almost every legal system in the world, namely Common Law, Civil Law, etc., recognizes its existence. The practice of business people or traders sees the principle of the parties' freedom to determine trade rules that apply between them as a crystallized principle. This principle, among other things, gave birth to the principle or doctrine of lex mercatoria. ${ }^{12}$

12 Wahyu Pratama Nur Anggara, "Hukum Perdagangan Internasional: Sejarah Dan Perkembangan Pokok Aturan Hukum,” Bakti Nusa, 2020. 


\subsection{Implications of the Policy War between Indonesia and the European Union}

A trade war is an economic conflict that occurs between two or more countries involving trade tariffs with one another. This conflict usually occurs when a country imposes or increases tariffs or other trade barriers in response to trade barriers set by the other party. The policy war that has occurred and is being carried out by both parties, namely Indonesia and the European Union, has triggered the possibility of a trade war that will have an impact on the economic system in the related countries. The European Union's policy of banning palm oil imports has more or less a detrimental impact on Indonesia as one of the largest palm oil producers in the world, with the European Union as the largest recipient of palm oil exports after India, amounting to 4.78 tons. This means, if the European Union imposes a policy to stop imports of palm oil, Indonesia will lose about 4.78 tons of palm oil that should be exported to the European Union. If the European Union is serious about implementing its policy of stopping all exports of palm oil, based on the amount of palm oil exported to the European Union, Indonesia will lose up to the US $\$ 858$ million or around Rp. 12 trillion, with a palm oil (CPO) price of around the US $\$ 572.5$ per ton. ${ }^{13}$

The European Union's policy of stopping or banning palm oil exports is carried out without clear grounds and considerations. The European Union considers that palm oil (CPO) has the impact of severe environmental damage and threatens the lives of living creatures in the forest. Although, as previously explained, palm oil (CPO) is the most environmentally friendly vegetable oil compared to other vegetable oils, which come from rapeseed and sunseed. Although the European Union issued a policy to stop exports of palm oil, on the other hand, the European Union continues to breed the production of rapeseed and sunflower seeds as vegetable oil for biodiesel. So it can be said that the EU policy overlaps with the use and production of other vegetable oils used as a substitute for CPO. This further reinforces the fact that the EU policy is carried out without foundation and is a random thing. ${ }^{14}$

In addition to the reasons mentioned above, to protect palm oil sales from retaining its market share, especially in the European and US markets, Indonesian palm oil farmers and entrepreneurs have started to improve the

\footnotetext{
${ }^{13}$ Nita Anggraeni, "Perang Dagang Dalam Hukum Perdagangan Internasional," UIN Sultan Maulana Hasanuddin Banten, 2019.

14 GAPKI, "Upaya Ubah Diskriminasi Sawit Uni Eropa: Indonesia Jangan Gelap Mata," Gabungan Pengusaha Kelapa Sawit Indonesia, 2019.
} 
production process for oil palm cultivation following the standards desired by the European market. And the United States. The Indonesian government has also implemented the Indonesia Sustainable Palm Oil System (ISPO) as proof that Indonesia is serious about improving the quality of domestic palm oil. Evidence of Indonesia's seriousness in improving domestic palm oil production can be seen from the decline in forest destruction due to oil palm cultivation, which previously reached 2 million hectares per year, to only 400 thousand hectares in 2018, and becomes even smaller in 2020. This means that Indonesia is serious about it. Improving palm oil production is not merely a discourse but has been manifested in the field, and the results have been proven. According to the Indonesian Palm Oil Producers Association (GAPKI), Europe is a perception maker where other countries follow every policy. Besides, Europe is used as a reference and example of world economic movements, in which many other countries have followed the steps taken by the European Union in overcoming the economic crisis. The action of the European Union in implementing the policy to ban palm oil exports has become a consideration for Japan and Pakistan in dealing with environmental issues caused by palm oil. ${ }^{15}$

\subsection{The Roots of Problems and the Solution of the Indonesian State in Facing the International Trade Cycle}

To follow up on the case of allegations of dumping from the European Union against the export of Indonesian biodiesel products, Indonesia then made steps to send a letter of objection to the dumping accusation to the European Union. The government submitted an objection letter to the European Union regarding the EU decision to impose an anti-dumping duty of $2.8 \%-9.6 \%$ for biodiesel from Indonesia. The objection letter was sent to the embassy in Jakarta. The government will send the letter through the Ministry of Trade. The dumping accusation that the European Union accuses of being inaccurate, the price of biodiesel is lower than the biodiesel produced by the European Union, and this is due to the cheap raw material for palm oil in Indonesia. The government, together with the sanctioned associations and companies, will continue to make efforts until September 2013. The next step is waiting for the EU to decide whether to continue the anti-dumping policy or not. The European

15 Rahayu and Sugianto, "IMPLIKASI KEBIJAKAN DAN DISKRIMINASI PELARANGAN EKSPOR DAN IMPOR MINYAK KELAPA SAWIT DAN BIJIH NIKEL TERHADAP PEREKONOMIAN INDONESIA." 
Union applies this anti-dumping import duty tariff that must be paid for six months or can be extended up to five years. Several companies such as Molinos Rio de la Plata SA, Aceitera General Deheza SA, and Pelita Agung Agrindustri are targeted to pay an anti-dumping import tax of 104.92 euros or the equivalent of Rp 1.3 million per metric ton, an increase of around 10.6\%. The definition of anti-dumping duty itself is a counter sanction in the form of additional import duty imposed on a product sold below the normal price of the same product in the exporting or importing country. So it can be understood that the penalties given by international institutions to countries that violate trade laws concerning the inequality between the normal or original price of the product and the price of the product to be exported or imported, the duty in question is a tax for the country that commits the violation. The products that are the focus are biodiesel made from palm oil, soybean oil, sunflower, or other materials from Indonesianowned resources. To deal with accusations of dumping by the European Union, things that can be done are understanding the anti-dumping provisions in the accusing country, as well as looking for facts in the field, and most importantly, using legal consultants who are experts in the field of anti-dumping. ${ }^{16}$

By making this effort, it is hoped that the EU will not be able to impose sanctions on Indonesia if it does not obtain definite and clear evidence directly. Therefore, in avoiding this practice, the Indonesian government formed an institution called KADI (Indonesian Anti-Dumping Commission) and following Article VI of the GATT, where the objectives of this institution are to participate and be active in realizing a fair and mutually exclusive world trade order. Profitable and also protects Indonesian producers against imports of dumped or subsidized goods from exporting countries, namely against dishonest trading practices, then these imports can harm the domestic importing industry. ${ }^{17}$

This began in 2006 to 2012. In 2006, namely, the existing legal instruments that were used as guidelines in making accusations and defending against dumping practices and the imposition of import duties were still government regulations, and if this continued, it could harm or interfere with developmentdomestic industry. Meanwhile, in 2012, the EU carried out anti-dumping duties on Indonesia due to the abnormal value of imported products. For now, the

\footnotetext{
16 Taufan Adharsyah, “Tak Disangka, Gara-Gara Ini Uni Eropa Hantam Sawit RI!,” CNBC Indonesia, 2019.

17 Sanny Cicilia, “Ekspor Biodiesel Ke Uni Eropa Kian Terpuruk,” Kontan Industri, 2014.
} 
difference between Indonesian biodiesel products based on palm oil is still around the US $\$ 180$ per ton cheaper than biodiesel produced by European companies, which is based on soybean oil.

Anti-dumping measures are the most frequently used measures to protect domestic industries. The reason is that this action is the most flexible and the least risky in conducting international trade. Also, a legal foundation is needed in the WTO, namely an emphasis on anti-dumping to create fair trade because it has been regulated in the Anti-Dumping Agreement or Agreement on the Implementation of Article VI of GATT 1994. Therefore, it is hoped that Indonesia will not carry out dumping practices anymore so that accusations of violations from world countries, especially the European Union with their biodiesel products, do not get sanctions in the form of additional import duties, which in turn make state revenues decrease and will kill the domestic market because they sell similar goods below the normal price of imported products country. ${ }^{18}$

Facing this case, Indonesia brought it to the International Trade Agency or WTO. Indonesia has notified the WTO Secretariat on June 10 and requests for consultation with the European Union (EU) on anti-dumping measures on biodiesel imports into the European Union. The steps that are being challenged by Indonesia are certain provisions of November 2009 regarding anti-dumping import measures from non-EU member countries regarding the determination of normal values in anti-dumping investigations; and anti-dumping on biodiesel imports originating from, among others, Indonesia, subject to May 2013 (temporary duty) and November 2013 (definitive duty). Indonesia claims that these actions are inconsistent with EU obligations under the Anti Dumping Agreement. ${ }^{19}$

Addressing the issue brought by the European Union in limiting palm oil, Indonesia issued a claim to refute the issue. Here are some of the claims by the Indonesian government to deny the black campaign carried out by the European Union: ${ }^{20}$

1. The largest GHG (greenhouse gas) emissions globally are carbon dioxide gas, which reached $92 \%$ of the total global GHG in 2011.

18 WTO, "European Union — Anti-Dumping Measures on Biodiesel from Indonesia," WTO, 2018.

19 WTO, "European Union - Anti-Dumping Measures on Biodiesel from Indonesia."

20 Muhammad Iqbal Fahreza, "Analisis Yuridis Terhadap Peranan WTO Dalam Menyelesaikan Sengketa Dagang Internasional,” Repositori Institusi USU, 2019. 
2. The largest sector in emitting $\mathrm{CO} 2$ is global energy/fossil fuel consumption. This sector contributes $56 \%$ of the total, while land development is $12.2 \%$.

3. The largest BBF emitters in the world are China, the United States, India, Russia, Japan, Germany, Iran, Canada, South Korea, and the United Kingdom.

4. The largest emitters of GHG from global agriculture are China, Brazil, India, the United States, the European Union, and Argentina.

5. Forest deforestation occurs in countries that have non-tropical forests, while countries with tropical forests tend to experience reforestation.

There are two ways of resolving WTO disputes, namely: (i) the parties solve an agreement, especially during the bilateral consultation stage; and (ii) through judicial proceedings, including the implementation of the Panel and Appellate Body reports in sequence, which are binding on the parties after being ratified by DSB.

In this regard, there are three main stages in settlement of the WTO target, namely: (i) consultation between the parties; (ii) trial by Panel or Appellate Body; and (iii) application of the award, including the possibility of countermeasure if the losing party fails to implement the result of the decision. Dispute settlement is the responsibility of the Dispute Settlement Body (DSB), which is the incarnation of the General Counsel (GC). The DSB is the only body with authority to establish a Panel of experts in charge of examining cases. DSB can also accept or reject the Panel's decision or the decision at the appeal level. The DSB monitors the implementation of decisions and recommendations and has the power/authority to legalize retaliation if a country does not comply with a decision. ${ }^{21}$

a. Consultation Phase Before taking further actions, the disputing countries must first negotiate (consultations) to find a solution to the differences of opinion between them. If that fails, they can also ask the Director-General of the WTO to mediate or help resolve the dispute. If consultations fail, the claimant country may request that a panel be formed. The defendant state can attempt to block the formation of the Panel once. Still, at the second DSB session, the formation of the

${ }^{21}$ Bradley, "Pengaturan Hukum Terhadap Produk CPO (Crude Palm Oil) Dan Dampak Terhadap Perdagangan Internasional." 
Panel can no longer be hampered (unless there is a consensus against the formation of the Panel. However, upon mutual agreement, it can also agree to follow the methods Other ways of resolving disputes in the form of good services (good offices), conciliation procedures, and mediation (mediation) In this regard, the good service, conciliation, and mediation mechanisms can continue even though the party that submitted the complaint has requested the formation of a panel. ${ }^{22}$

b. Panel Stage The Panel Stage is a procedure in which the plaintiff can fight for the rights or benefits of the WTO Agreement and, on the other hand, allow the defendant to defend himself. This stage is intended to decide disputes, and the parties are obliged to accept the verdict because it is binding. Panel requests can only be requested by one party without the consent of the other party, which is a step forward from previous GATT practices. The request for the formation of the Panel must be stated in writing stating the reasons, the steps that have been taken regarding the matter, and the legal basis for the claim. If there is no response within the stipulated timeframe, the party requesting consultation may request the formation of a panel. The function of the Panel in dispute resolution is to assist DSB in carrying out the obligations stipulated by DSU and covered agreements, namely to provide an objective assessment of the problems it submits to be handled. The Panel was also asked to carry out regular consultations with the disputing parties. ${ }^{2324}$

c. Appeal Stage Each disputing party can appeal to the Panel's decision. Sometimes both parties file an appeal. However, the appeal must be based on a certain rule, such as a legal interpretation of a provision/article in a WTO Agreement. Do not appeal to reexamine existing evidence or new evidence that emerged, but rather to examine the arguments put forward by the Panel Decisions at the appellate level can enforce, amend or reverse the findings and legal decisions of the Panel. Usually, an appeal takes no more than 60 days and a maximum

${ }^{22}$ Bradley, "Pengaturan Hukum Terhadap Produk CPO (Crude Palm Oil) Dan Dampak Terhadap Perdagangan Internasional."

23 Ibid, hal 65

24 Bradley, "Pengaturan Hukum Terhadap Produk CPO (Crude Palm Oil) Dan Dampak Terhadap Perdagangan Internasional." 
limit of 90 days. DSB must accept or reject the appeal report within not more than 30 days, where rejection is only possible by consensus. ${ }^{25}$

d. Dispute Resolution After Recommendation or DSB Decision If a country has violated WTO rules by establishing rules that are inconsistent with the WTO, that country must immediately correct its mistakes by aligning its rules with WTO rules. If the country still violates WTO rules, it must pay compensation or be subject to "retaliation." Usually, compensation/retaliation is applied in the form of concessions or market access. In this stage, the most important thing is that the "defendant" must align his policies with the DSB recommendations or decisions. The WTO agreement on dispute resolution stipulates that "prompt action in terms of complying with the recommendations or decisions of the DSB is very important to ensure that the resolution decisions are effective and benefit all WTO members." Countries that lose to the dispute must follow the recommendations stated in the panel report (Panel Report) or the appeal report (Appellate Body). ${ }^{26}$

The winning country in the dispute can determine the compensation that is acceptable to all parties and can ask DSB for permission to apply a limited trade sanction against the country that is losing to the dispute if the country that loses the dispute cannot implement the recommendations or decisions that have been approved by DSB in a predetermined period. ${ }^{27}$

\section{Conclusion}

The European Union has taken issue with Indonesia's palm oil exports for reasons related to health and environmental issues. Indonesian palm oil is said to be high in saturated fat, poor management, and also land clearing, which results in global warming and deforestation. Palm oil is a priority for Indonesia's largest export commodity. Clearing land that is used for palm oil also provides the potential for opening job vacancies that will solve the problem of unemployment in Indonesia. Therefore, the Indonesian government tries to refute the facts of

25 Bradley, "Pengaturan Hukum Terhadap Produk CPO (Crude Palm Oil) Dan Dampak Terhadap Perdagangan Internasional."

26 Bradley, "Pengaturan Hukum Terhadap Produk CPO (Crude Palm Oil) Dan Dampak Terhadap Perdagangan Internasional."

27 Mariatulkubtia, "Peran WTO Dalam Menjembatani Benturan Kepentingan Antara Uni Eropa Dan Indonesia Dalam Perdagangan Biodiesel.” 
the findings of the European Union by conducting various studies. The results of the research proved that what the European Union had allegedly contradicted the findings.

The European Union's accusation of environmental threats is considered impure as environmental protection. Many argue that the accusation is only a political step by the European Union in anticipating the development of Indonesian $\mathrm{CPO}$ product exports to Europe. So to test the truth of the allegation, whether it is purely environmental protection or just a political step, Indonesia has conducted various studies on CPO products in Indonesia. The research conducted shows that Indonesian $\mathrm{CPO}$ products have not caused environmental damage on a large scale as accused by the European Union. This strengthens the indication of discrimination against Indonesian CPO products by the European Union. There are indications that the European Union is starting to worry about the high export value of Indonesian CPO products, which is beginning to dominate the European market. So that to prevent a higher spike, efforts were made to drop Indonesian CPO products.

The country that is losing to the dispute must follow the recommendations stated in the panel report (Panel Report) or the appeal report (Appellate Body). The country that wins the dispute can determine the compensation that is acceptable to all parties and can ask DSB for permission to apply a limited trade sanction against the country that is losing to the dispute if the country that loses the dispute cannot implement the recommendations or decisions that have been approved by DSB in a predetermined period.

\section{Conflict of Interest}

The authors declared that they have no conflicts of interest.

\section{Acknowledgments}

A big thank you to Diani Sadiawati, SH, LLM, PhD from the Department of International Law Pembangunan Nasional Veteran Jakarta University for guiding us in international law courses

\section{Author Contribution}

Yana Sylvana played a role in sparking research ideas and making the manuscript. Yohanes Firmansyah contributed in making the manuscript and translating the 
language. Hanna Wijaya was in charge of finding journal compilation material. Michelle Angelika S contributed to arranging the writing format and revising the manuscript

\section{Funding}

Self Funding

\section{Reference}

Adharsyah, Taufan. "Tak Disangka, Gara-Gara Ini Uni Eropa Hantam Sawit RI!” CNBC Indonesia, 2019.

Anggraeni, Nita. "Perang Dagang Dalam Hukum Perdagangan Internasional." UIN Sultan Maulana Hasanuddin Banten, 2019.

Bradley, Alexander. "Pengaturan Hukum Terhadap Produk CPO (Crude Palm Oil) Dan Dampak Terhadap Perdagangan Internasional.” USU, 2019.

Cicilia, Sanny. "Ekspor Biodiesel Ke Uni Eropa Kian Terpuruk.” Kontan Industri, 2014.

Dewi, Rosita. "Implementasi Renewable Energy Directive Uni Eropa, Dalam Jurnal Interdependence.” Jurnal Interdependence 1 (2013): 151.

Ermawati, Tutii, and Saptia Yeni. "Kinerja Ekspor Minyak Kelapa Sawit Indonesia." Buletin Ilmiah Litbang Perdagangan. Jakarta, 2013.

Fahreza, Muhammad Iqbal. "Analisis Yuridis Terhadap Peranan WTO Dalam Menyelesaikan Sengketa Dagang Internasional." Repositori Institusi USU, 2019.

GAPKI. "Upaya Ubah Diskriminasi Sawit Uni Eropa: Indonesia Jangan Gelap Mata." Gabungan Pengusaha Kelapa Sawit Indonesia, 2019.

Ibrahim, Johny. Teori \& Metodologi Penelitian Hukum Normatif, 2006.

Mariatulkubtia, Anggi. "Peran WTO Dalam Menjembatani Benturan Kepentingan Antara Uni Eropa Dan Indonesia Dalam Perdagangan Biodiesel." Andalas Journal of International Studies (AJIS) 9, no. 1 (2020): 16. https://doi.org/10.25077/ajis.9.1.16-33.2020.

Nur Anggara, Wahyu Pratama. "Hukum Perdagangan Internasional: Sejarah Dan Perkembangan Pokok Aturan Hukum.” Bakti Nusa, 2020. 
Yana Sylvana, Yohanes Firmansyah, Hanna Wijaya, Michelle Angelika S

Rahayu, Sekar Wiji, and Fajar Sugianto. "IMPLIKASI KEBIJAKAN DAN DISKRIMINASI PELARANGAN EKSPOR DAN IMPOR MINYAK KELAPA SAWIT DAN BIJIH NIKEL TERHADAP PEREKONOMIAN INDONESIA.” Jurnal Ilmu Hukum 16 (2020).

Report, World Growth. “The Economic Benefit of Palm Oil to Indonesia," 2011. Sally, N U. "Sengketa Minyak Sawit Antara Indonesia Dan Uni Eropa." Dauliyah Journals 1, no. 1 (2016): 1-11. https://doi.org/10.1186/s40563-016-00628.

Skoog, Oloff. "Facts about the EU and Palm Oil."The Jakarta Post, 2015.

WTO. "European Union - Anti-Dumping Measures on Biodiesel from Indonesia."WTO, 2018. 
